\title{
A New Troglobitic Isopod of the Genus Lirceus (Asellidae) from Southwestern Virginia, with Notes on its Ecology and Additional Cave Records for the Genus in the Appalachians
}

\author{
by
}

\author{
John R. HOLSINGER* and Thomas E. BOWMAN
}

Department of Invertebrate Zoology, National Museum of Natural History

Smithsonian Institution, Washington, D.C. 20560

\section{INTRODUCTION}

Among the freshwater isopod crustaceans of the family Asellidae in the United States, the genus Asellus (s. lat.) is widespread in both epigean and cave habitats and is represented by numerous troglobitic species (i.e., obligatory cavernicoles). The genus Lirceus, on the other hand, is almost always found in epigean habitats (especially springs and small streams), and previous to this paper, troglobitic forms had not been described. Although various species of Lirceus have been reported from caves in Missciuri by Hubricht and Mackin (1949), caves in Tennessee by Barr (1961) and caves in Georgia by Holsinger and Peck (1971), none of these are apparently restricted to cave waters or show any of the extreme morphological modifications usually associated with troglobites.

During extensive biological investigations of caves in the central Appalachian region, populations of blind, white Lirceus were discovered by one of us (J.R.H.) in three caves in the Fowell Valley of Lee County, Virginia. In addition to being the first known eyeless form of the genus, this material differs in several important ways from any of the known species of Lirceus and is described below.

Additional populations of Lirceus have also been discovered in the caves of southwestern Virginia and eastern Tennessee (primarily in the Clinch and Powell River valleys), but these animals are usually lightly pigmented, possess small eyes and differ morphologically from the newly described species. Because of the taxonomic confusion in the genus Lirceus (see Styron, 1969 and Williams, 1972), we have been unable to determine whether these additional populations represent one or more undescribed species or belong to previously described forms. For assistance in future studies, however, these localities are listed at the end of the paper.

In their evaluation of the characters used to distinguish species in Lirceus, Hubricht and Mackin (1949) conclude that the male pleopods 1 and 2 are of doubtful value. In particular, they state that the tip of the endopod of pleopod 2 , "which is Asellus differs so completely from species to species, in Lirceus differs

\footnotetext{
* Permanent Address: Department of Biology, Old Dominion University, Norfolk, Virginia 23508.
} 
only by slight variations in a single basic pattern." Later in the same paper they state that Lirceus bidentatus is the only species which can be distinguished by the male pleopod 2. In this species the spur is "greatly enlarged, equalling in length the diameter of the endopodite." Unfortunately, Hubricht and Mackin did not provide illustrations of the endopod tip of L. bidentatus or of any other species of Lirceus.

It seems to us, even with our limited experience with the systematics of Lirceus, that the value of the endopod tip as a taxonomic character should not be dismissed so lightly. Excellent illustrations of this structure are provided by Racovitza (1920) for L. lineatus (Say) ((as Mancasellus tenax (Smith)) and L. fontinalis Rafinesque (as Mancasellus macrourus Garman); copies of Racovitza's figures are given by Henry and Magniez (1970). The endopod of $L$. brachyurus is illustrated by van Schaik (1949) in her doctoral dissertation. Since this dissertation was never published, we include a drawing of the L. brachyurus endopod here (Figure 3A). When the illustrations of the endopod tips of the above three species of Lirceus and that of L. usdagalun, new species (Figure 3D) are compared, clearcut differences are immediately apparent, and we are convinced that the endopod tip will prove valuable for distinguishing the species of Lirceus. In the section on Relationships, we compare the endopod tip of L. usdagalun with those of two related species.

All of the material examined in this study is deposed in the National Museum of Natural History, Smithsonian Institution (USNM).

\section{Lirceus usdagalun new species Figures 1, 2, 3B-J}

Lirceus species. - Culver, 1973:102-110.

Material Examined. Lee County, VIRGINIA: Gallohan Cave No. 1, holotype male (USNM 143680) and 18 paratypes (USNM 143681), J.R. Holsinger and David C. Culver, 26 August 1971; Surgener Cave, 7 paratypes (USNM 143683), J.R. Holsinger and William Mauck, 18 August 1961 and 7 paratypes (USNM 143682), J.R. Holsinger, D.C. Culver and James M. Beck, III, 26 August 1971; Thompson Cedar Cave, 42 paratypes (USNM 143684), J.R. Holsinger, Donald L. Finley and John Tichenor, 30 July 1967 and 14 paratypes (USNM 143685), J.R. Holsinger, D.C. Culver and Russell M. Norton, 26 November 1971.

Diagnosis. A small, eyeless, unpigmented species, reaching a length of $7.0 \mathrm{~mm}$ to $7.5 \mathrm{~mm}$. Distinguished by deep, narrow lateral incision of the head, relatively wide spaces between the anterior pereonites, absence of median and distal processes on the palm of the gnathopodal propod (excepting larger males which have a rudimentary median process), slender spur of the endopod of the male second pleopod, and proportionately short uropod.

Description. Body about 64 percent longer than wide, with subparallel sides, not widening posteriorly. Head about $1 / 3$ as long as wide; lateral margin narrowly and deeply incised, anterior lobe about twice as wide as posterior lobe. Pereonites subequal, margins covered with fine setae. Pleotelson subtriangular, about 27 percent as long as body, about $1 / 3$ broader than long, narrowing posteriorly; median posterior process poorly delimited. 


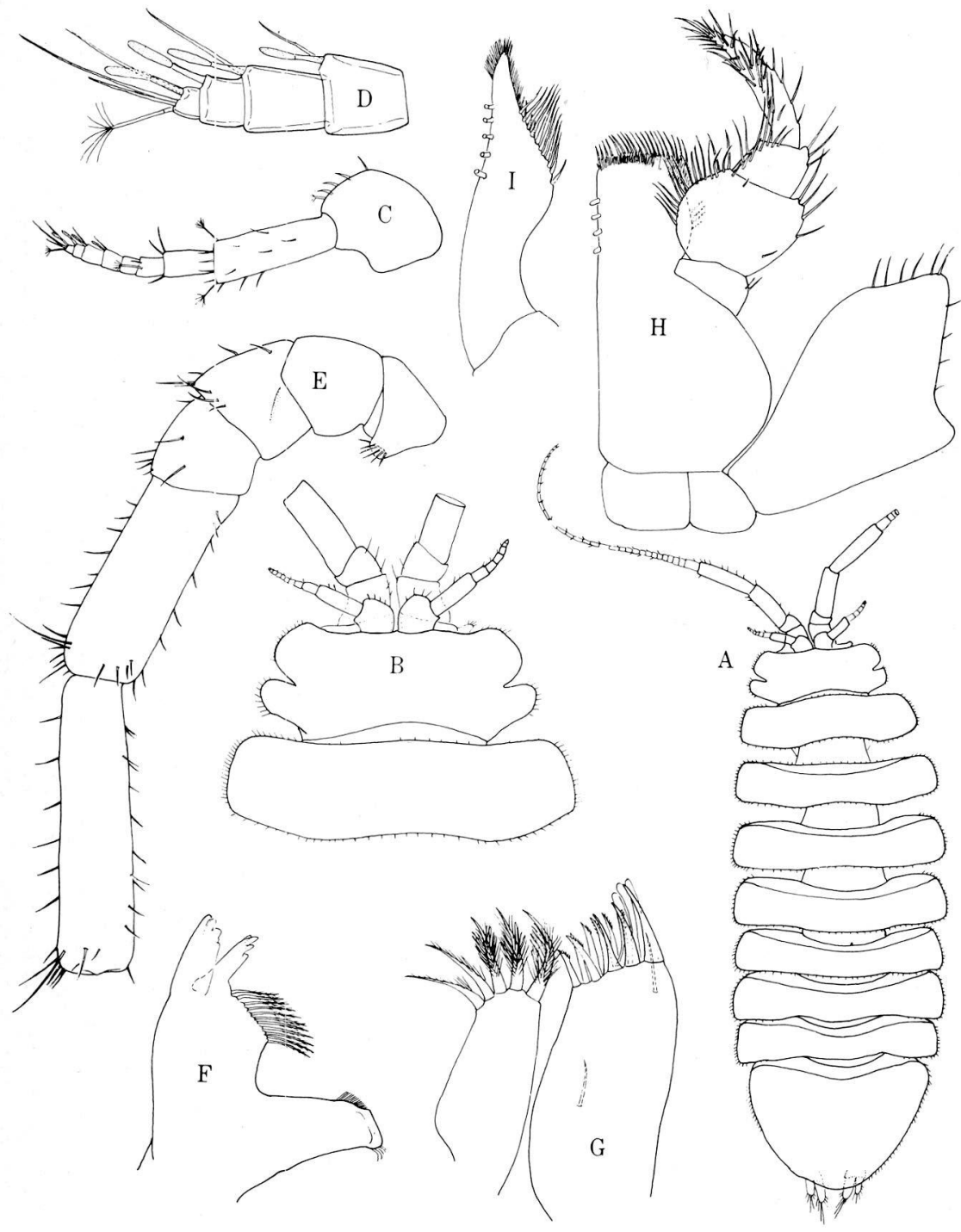

Fig. 1. Lirceus usdagalun, new species. A-E, G, $7.0 \mathrm{~mm}$ female, Gallohan Cave No. 1; H, I, $7.0 \mathrm{~mm}$ male, Gallohan Cave No. 1; F, $6.0 \mathrm{~mm}$ male, Thompson Cedar Cave. A, dorsal view; $\mathrm{B}$, head and pereonite $1 ; \mathrm{C}$, left antenna 1 , dorsal; $\mathrm{D}$, terminal segments of antenna 1, dorsal; E, right antenna 2, ventral; F, left mandible; $G$, right maxilla 1 ; $H$, left maxilliped, posterior; I, endite of right maxilliped, medial. 


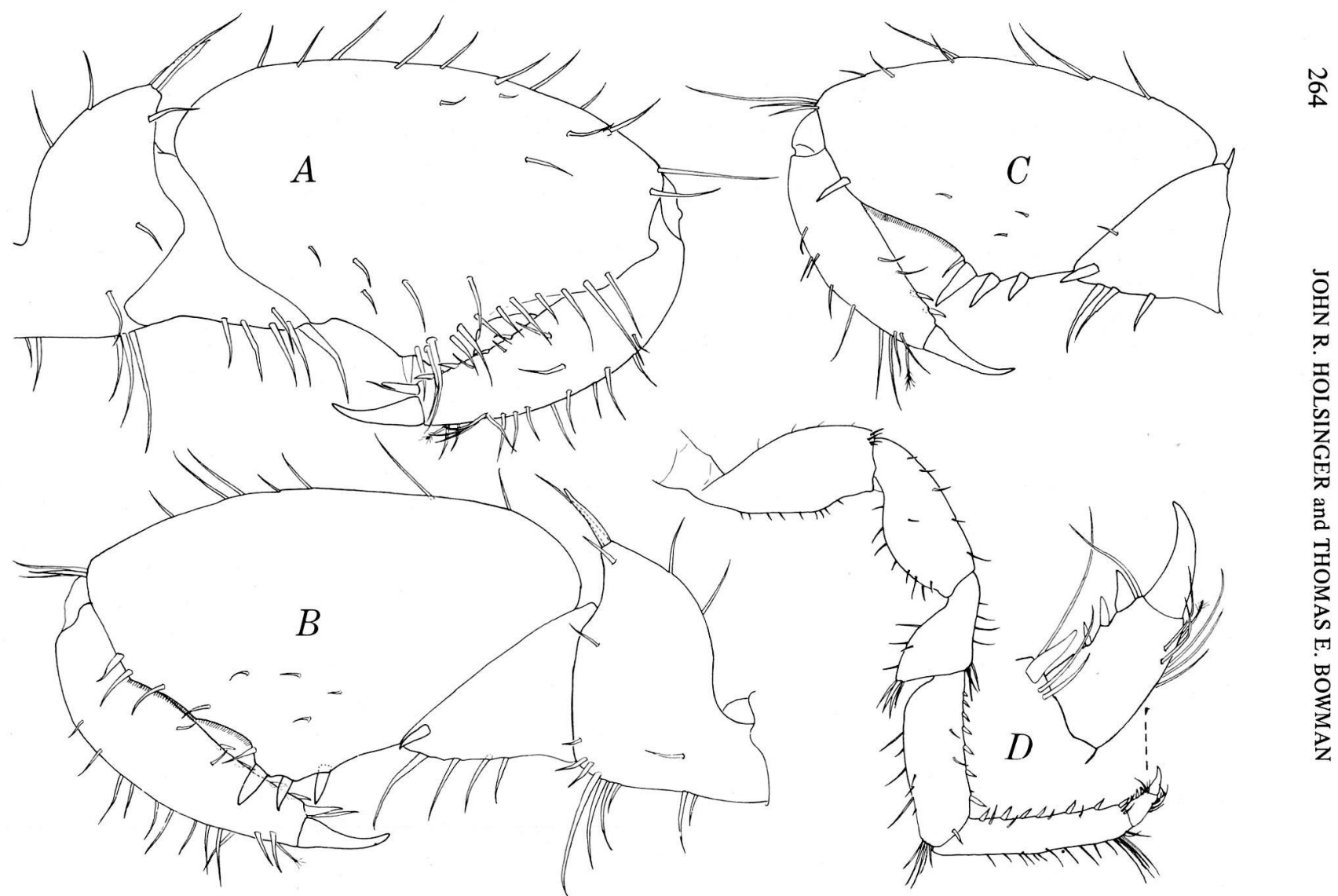

Fig. 2. Lirceus usdagalun, new species, A,B, D, 7,0 mm male, Gallohan Cave No. 1; C, 7.0 mm female, Gallohan Cave No. 1. $\mathrm{A}$, right gnathopod, lateral; B, same, medial; C, right gnathopod, medial; D, right pereopod 7. 
Antenna 1: flagellum 6-segmented, last 4 segments each bearing 1 esthete anterodistally; first 2 peduncular segments and first and last flagellar segments with tufted setae.

Antenna 2: relatively long, 70 to 75 percent as long as body; first segment of peduncle with conspicuous spinose lateral lobe; peduncular segments 5 and 6 subequal, each longer than first 4 segments combined; flagellum with up to 30 segments. Mandible without palp; incisor and lacinia mobilis 4-cuspidate; spine row with 11 plumose spines on left and 14 or 15 on right (in material examined); molar bearing clusters of subapical setae.

Maxilla 1: outer lobe with 13 apical spines, outermost 4 longer than inner ones, with rounded tips; inner lobe with 5 apical, plumose spines. Maxilliped with 4 or 5 retinaculae; apex of endite covered with dense pubescense and bearing also row of stiff, close set setae or slender spines; segments of palp with numerous setae.

Gnathopodal propod of male proportionately small, rather weak (in comparison to most other species of Lirceus); palm rather oblique, with small proximal process bearing 3 heavy spines; median process of palm rudimentary. Gnathopodal propod of female proportionately smaller than that of male; palm more oblique, proximal process smaller, median process absent.

Male pleopod 1: peduncle slightly shorter than exopod, with 3 retinaculae; exopod slightly less than twice as long as wide; inner margin of exopod straight, unarmed; outer margin of exopod convex, armed with long setae; apex bearing shorter setae. Male pleopod 2: peduncle about 1/3 longer than wide, distomedial margin serrulate. Exopod of male pleopod 2 slightly more than 1/2 length of peduncle; distal segment subquadrate, bearing 3 long, barbed apical setae and 5 long, naked setae on lateral margin. Endopod of male pleopod 2 subolong, about twice as long as broad; apex with 3 distinct processes and 1 spur. Caudal process broadly rounded, margin partly rugose, cephalic process smaller and less broadly rounded than caudal process, anterior surface rugose; mesial process with short stalk and flattened tip bent anteriad; spur slender, finger-like, slightly curved, apparently arising from inner surface of cephalic process. Female pleopods 2 short, fused at base; lateral margins convex; apexes each bearing 2 terminal setae and 1 shorter subterminal seta. Pleopod 3 of both sexes similar to that of L. fontinalis (syn. $\neq$ L. macrourus) but with somewhat fewer setae on anterior surface of exopod. Exopod of pleopod 4 with conspicuous pleat on anterior surface. Exopod of pleopod 5 with single seta on proximal part of lateral margin.

Uropod about 0.07 length of body, about 1/3 length of pleotelson; peduncle about as broad as long, subequal in length to exopod; endopod about $1 / 3$ longer than exopod; rami bearing long terminal setae.

Type-Locality. -- Gallohan Cave No. 1, $11 \mathrm{~km}$ southeast of Rose Hill, Lee County, Virginia. The type-locality is developed in the Hurricane Bridge limestone of Middle Ordovician age and is situated about 610 meters north-northest of the entrance to Surgener Cave. The stream in Gallohan Cave No. 1 is a tributary to the larger stream in Surgener Cave and these two caves, along with nearby Gallohan Cave No. 2, make up the Surgener-Gallohan Cave System. Although these caves are connected hydrologically, a human physical connection has not been made between 

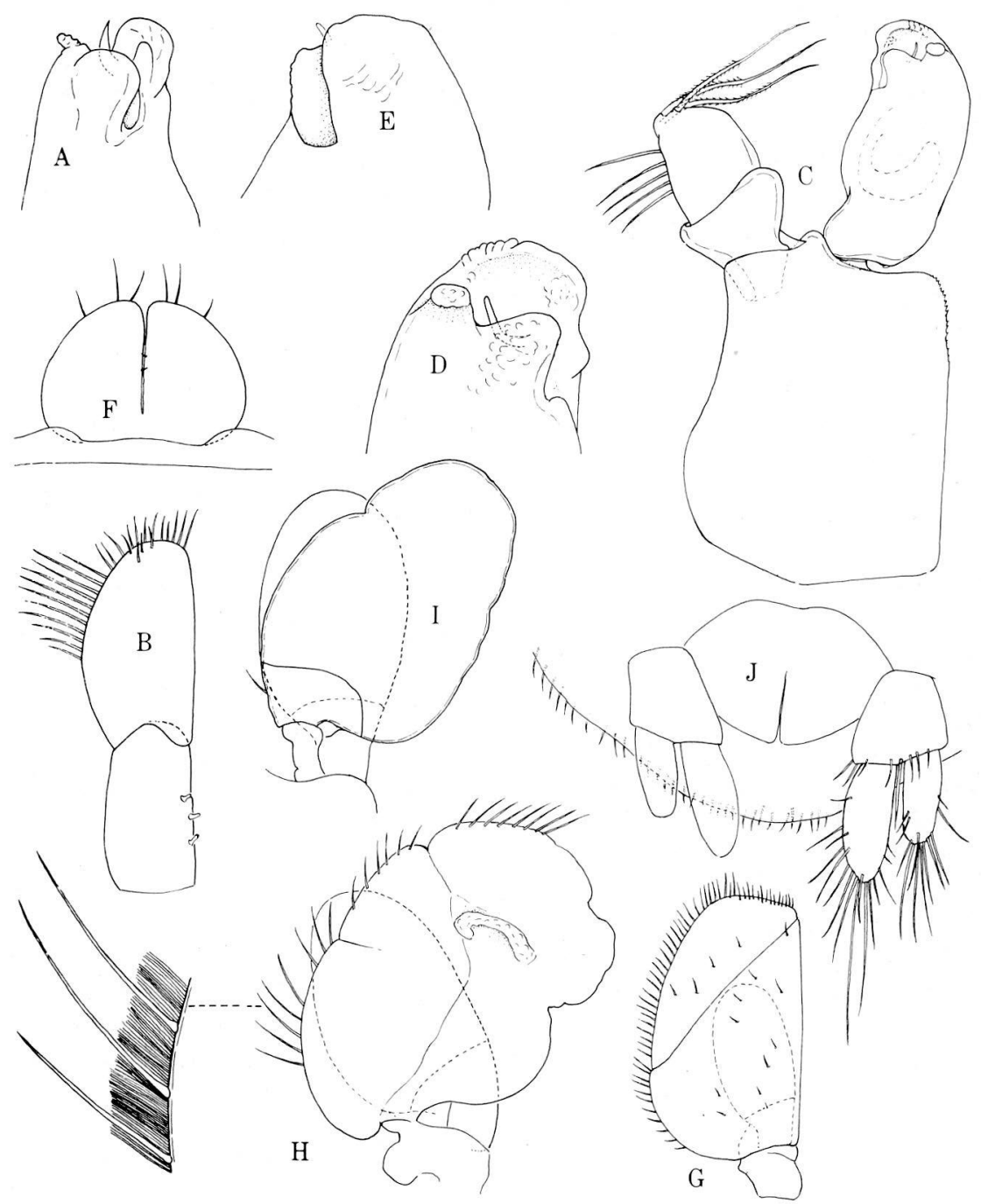

Fig. 3. Lirceus brachyurus (Harger). A, tip of endopod of pleopod 2 of male from Lacey Springs, Virginia. Lirceus usdagalun, new species. B-E, $7.0 \mathrm{~mm}$ male, Gallohan Cave No. 1; F-1,6.0 mm female, Thompson Cedar Cave; J, 7.0 mm female, Gallohan Cave No. 1. B, pleopod 1, anterior; C, pleopod 2, anterior; D, tip of endopod of pleopod 2, anterior; E, same, posterior; F, pleopod 2, anterior; G, pleopod 3, anterior; H, pleopod 4, anterior; I, pleopod 5, anterior; J, uropods and apex of telson, ventral. 
them. The type-series of 14 females and 5 males was collected from under and on top of small rocks in the cave stream. This stream also contains other aquatic troglobites, including the isopod Asellus recurvatus, the amphipod Crangonyx antennatus, the planarian Sphalloplana sp. (probably $S$. virginiana), and the snail Fontigens sp. The snails and planarians are much less abundant than the isopods and amphipods.

Etymology. - "Usdagalun" is a Cherokee noun meaning "cave" or "hole under rock". We consider the name appropriate since the Cherokee Indians formerly inhabited the Powell Valley of southwestern Virginia and eastern Tennessee.

Relationships. - Attempts to make critical comparions of L. usdagalun with other species in the genus are difficult. The problems inherent in the taxonomy of Lirceus, such as the possible lack of a singular diagnostic character useful for distinguishing species and the extreme variation and probable intergradation between species, have been discussed by Styron (1969) and Williams (1972). Of the 13 species in the genus recognized by Hubricht and Mackin (1949), three ( $L$. brachyurus, L. fontinalis and L. hargeri) occur in the Appalachian region and therefore might be expected to show some relationship to L. usdagalun.

Lirceus brachyurus (eastern Pennsylvania southwest to Rockbridge County, Virginia) is similar to L. usdagalun in having proportionately short uropods (about $1 / 3$ the length of the pleotelson) and in the absence (or near absence) of the median and distal marginal processes of the male gnathopodal propod. L. brachyurus differs by being larger at sexual maturity, lacking lateral incisions of the head and in the structure of the tip of the endopod of the second male pleopod. In L. brachyurus the caudal process is much smaller and more sharply rounded, the mesial process is smaller and not flattened distally and the spur tapers to a sharp, apical point (see Figure 3A).

Lirceus fontinalis (Illinois, Indiana and Ohio south to northwestern Georgia) is similar to L. usdagalun in having lateral incisions of the head but differs in being much larger at sexual maturity, having proportionately longer uropods ( $1 / 2$ to $2 / 3$ the length of the pleotelson), 2 or 3 palmar margin processes on the male gnathopodal propod and in the structure of the tip of the endopod of the second male pleopod. In $L$. fontinalis (see Racovitza, 1920, figs. 127, 128), the mesial process is smaller (like that of $L$. brachyurus) and the spur is shorter, thicker and not finger-like.

Lirceus hargeri (known only from a few springs in the Powell and Holston valleys of Virginia and Tennessee) is similar to L. usdagalun in the possession of lateral incisions of head but differs in being larger at sexual maturity, having three palmar margin processes on the male gnathopodal propod and having proportionately longer uropods (about $2 / 3$ the length of the pleotelson).

\section{DISTRIBUTION AND ECOLOGY}

The distribution of L. usdagalun is shown on the map in Figure 4. This species is at present known only from three caves in the Powell Valley of south-certral Lee 
County. As already mentioned, Gallohan and Surgener caves are a part of a single, hydrologically integrated, subterranean system. Thompson Cedar Cave is situated $10 \mathrm{~km}$ northeast of the Surgener-Gallohan System, and all three caves are developed in a broad band of low-dipping, Middle Ordovocian limestone (Hurricane Bridge and Martin Creek members) on the southern flank of the Cedar Syncline. This broad, gently dipping band of limestone, which extends through south-central Lee County, contains numerous caves and undoubtedly facilitates the subterranean dispersal of cavernicoles along its corridor. It might be surprising, then, that extensive searching in caves with aquatic habitats lying between Thompson Cedar Cave and the Surgener-Gallohan System has failed to reveal additional populations of this species. However, competition between the various cavernicolous crustaceans of this area for food and space such as those discussed by Culver (1973) may very well be responsible for the apparent restriction of this species to the caves noted. Virtually all caves in the Powell Valley with small streams and/or pools contain populations of the amphipod Crangonyx antennatus and many contain the isopod Asellus recurvatus. Gallohan Cave No. 1, however, is the only cave of those studied which contains both $L$. usdagalun and $A$. recurvatus in the same stream. It is perhaps also significant that in the stream in Thompson Cedar Cave, A. recurvatus is absent but that $L$. usdagalun is very abundant, along with a small population of $C$. antennatus.

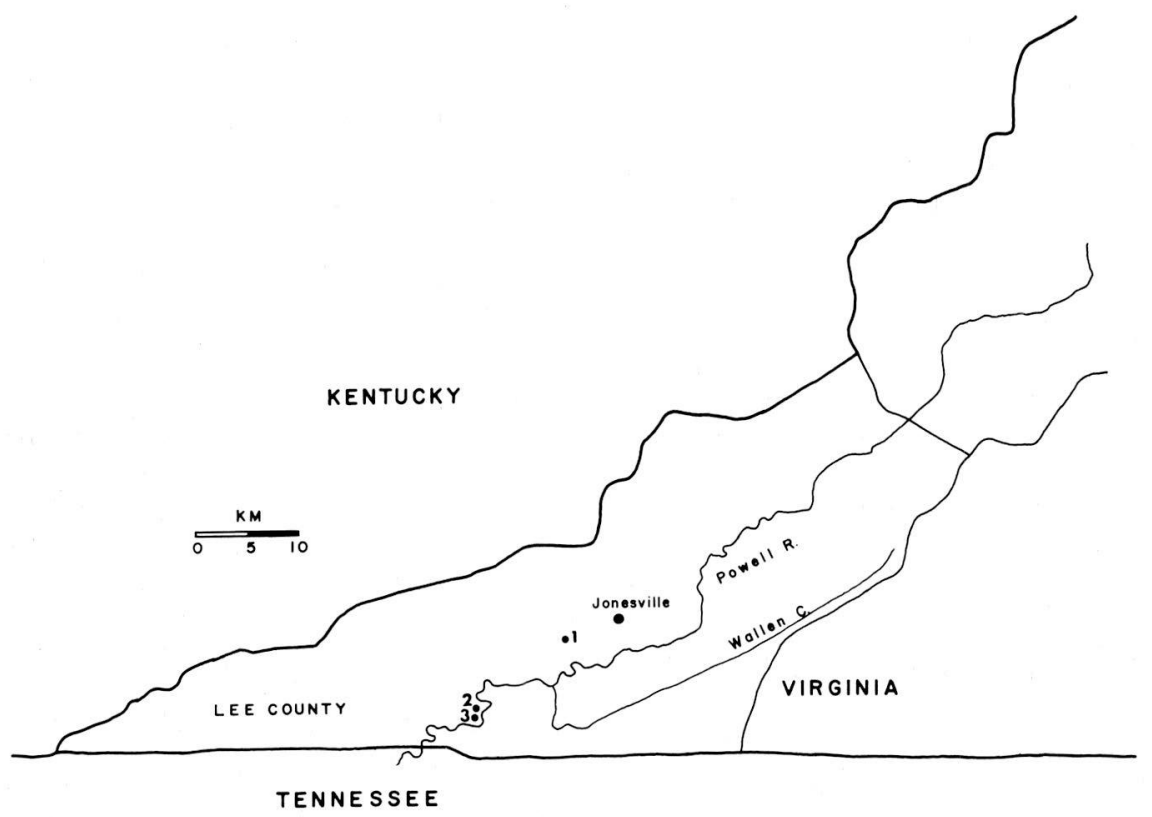

Fig. 4. Distribution of Lirceus usdagalun, new species in Lee County, Virginia: 1, Thompson Cedar Cave; 2, Gallohan Cave No. 1; 3, Surgener Cave. 
Lirceus usdagaiun is usually found either on the upper or lower surfaces of small rocks submerged in streams, although it has also been collected from among small stream gravels. The spatial distribution and microhabitat preference of Lirceus, Asellus and Crangonyx have been diagramed in detail by Culver (1973) for populations in the streams of the Surgener-Gallohan System.

Of the 89 specimens of $L$. usdagalun sampled from the three caves (total of five samples), 73 were females and 16 were males, giving a sex ratio of approximately 4.5 to 1 in favor of females. Of the 73 females, five were either ovigerous or larviparous and ranged in size from $4.5 \mathrm{~mm}$ to $6.5 \mathrm{~mm}(\overline{\mathrm{x}}=5.6 \mathrm{~mm})$. Only the July and August samples contained ovigerous or larviparous females. The average number of eggs per female was 27.5 , but this calculation was based on only three females; the other two were carrying newly hatched young (larvae) and some of the young had apparently been released prior to collection. The newly hatched young varied in length from $1.0 \mathrm{~mm}$ to $1.3 \mathrm{~mm}$. The size ranges for animals large enough to be sexed were: females, 2.5 to $7.5 \mathrm{~mm}$; males, $3.5 \mathrm{~mm}$ to $7.1 \mathrm{~mm}$.

\section{Cave Localities for Lirceus Spp.}

Small, eyed, often lightly pigmented Lirceus have been collected and/or observed in a number of caves in the upper Tennesse River drainage basin of eastern Tennessee and southwestern Virginia. With the exception of the populations in Fallen Rock and High Young caves (treated separately as sp. B. below), these populations appear to be represented by a single, as yet undetermined or undescribed species. This form (sp. A) is characterized by the lateral margins of the head which extend outward on each side posteriorly to form a small lobe. An annotated list of these localities follows.

\section{Lirceus Sp. A}

TENNESSEE. Clairborne County: Billingsley Cave near Arthur, 8 specimens (including 1 ovigerous female) collected from stream, 20 Aug. 1972. Hancock County: Lawsons Cave No. 3 near Sneedville, 1 male collected from stream, 24 Aug. 1972. Roane County: Berry Cave south of Kingston, 8 specimens collected 15 July 1964.

VIRGINIA. Lee County: Bailey Cave near Dryden, 1 female collected from under rock in stream, 29 Nov. 1969; Olinger Cave about $5.5 \mathrm{~km}$ southeast of Jonesville, 2 females collected from rock in small stream, 24 Aug. 1972; Young-Fugate Cave near Gibson Station, 11 specimens collected from stream, 15 Aug. 1965. Scott County: Coley Cave No. 2 near Gate City, 2 females and 1 juvenile collected 18 Aug. 1972 and 9 specimens (including 1 ovigerous female) collected 3 June 1967, all from under rocks in stream; Speers Ferry Cave near Speers Ferry, many specimens observed in gravels and on rocks in stream, 28 Aug. 1971; Wolfe Cave (same stream as in Speers Ferry Cave, above), 2 females collected from under flat rocks in stream, 14 Aug. 1969. Washington County: Singleton Cave about $8 \mathrm{~km}$ northwest of Abingdon, 12 specimens collected from gravels and under flat rocks in small stream, 9 Dec. 1967. 


\section{Lirceus sp. B.}

VIRGINIA. Tazewell County: Fallen Rock Cave near Liberty, 25 specimens collected from under flat rocks in stream, 9 Nov. 1968 and 5 specimens collected 30 Aug. 1971; Hugh Young Cave near Liberty, a number of specimens observed on several occasions under flat rocks in stream.

Fallen Rock and Hugh Young caves are part of a large, hydrologically integrated, subterranean drainage system located in the Ward Cove-Maiden Spring karst area of southwestern Tazewell County near the headwaters of the Clinch River. Fallen Rock Cave contains a large population of Lirceus which extends along the stream for several kilometers. In nearby Hugh Young Cave, Lirceus is found under rocks in the stream, and beyond 90 meters from the entrance it is associated with a population of the troglobitic isopod Asellus richardsonae. The Lirceus in these two caves have very tiny eyes (in comparison to epigean populations) and are very lightly pigmented, or in some specimens appear to lack pigment altogether. Morphologically, this form differs from Lirceus sp. A primarily in the structure of the head which lacks the porterior lobes. In respect to the shape of the head, Lirceus sp. B closely resembles $L$. brachyurus.

\section{ACKNOWLEDGEMENTS}

For their assistance with the fieldwork we thank James M. Beck, III, David C. Culver, Donald L. Finley, William Mauck, Russell M. Norton and John Tichenor. We also owe a debt of gratitude to the many landowners in southwestern Virginia and eastern Tennessee who have allowed us to visit their caves and collect specimens. We thank Dr. D.C. Culver for reading the manuscript and making helpful suggestions and Dr. William C. Sturtevant (Department of Anthropology, Smithsonian Institution) for supplying us with the Cherokee word for cave.

\section{SUMMARY}

Lirceus usdagalun new species, the first known troglobitic species of the genus, is described from three caves in Lee County, Virginia. The potential taxonomic value of the endopod tip of the male second pleopod, heretofore dismissed as a diagnostic character in this genus, is pointed out. Some general ecological data for the new species are presented, and cave records for other populations of Lirceus spp. from the Appalachians are given.

\section{RÉSUMÉ}

Description de Lirceus usdagalun n.sp., première espèce troglobie connue de ce genre, découverte dans trois grottes de Lee County (Virginie). 
La valeur taxonomique spécifique potentielle de la conformation de l'extrémité du second pléopode mâle, caractère négligé précédemment et relégué au niveau de la diagnose du genre, est mise en évidence ici.

Des données écologiques d'ordre général sur la nouvelle espèce sont exposées et de nouvelles stations cavernicoles de populations de Lirceus sp., localisées dans la chaîne des Appalaches, sont citées.

\section{REFERENCES}

BARR, T.C. Jr. 1961. Caves of Tennessee. Tennessee Dept. Conserv. and Commerce, Div. Geol., Bull. $64,567 \mathrm{pp}$.

CULVER, D.C. 1973. Competition in spatially heterogeneous systems: An analysis of simple cave communities. Ecology, 54 (1):102-110.

HENRY, J.-P. and G. MAGNIEZ, 1970. Contribution à la systématique des asellides (Crustaccea Isopoda). Annal. de Spéléol. 25 (2):335-367.

HOLSINGER, J.R. and S.B. PECK. 1971. The invertebrate cave fauna of Georgia. Bull. Nat. Speleol. Soc., 33 (1):23-44.

HUBRICHT, L. and J.G. MACKIN. 1949. The freshwater isopods of the genus Lirceus (Asellota, Asellidae). Amer. Midl. Nat1., 42 (2):334-349.

RACOVITZA, E.G. 1920. Notes sur les isopodes. 8. Mancasellus tenax (Smith) - 9. Mancasellus macrurus Garman. Arch. Zool. Expér. Gén., 59:28-66.

SCHAIK, M.W. VAN. 1949. A comparative study of the abdomen of three freshwater isopods (Isopoda, Asellidae). Unpublished doctoral dissertation, University of Virginia, 122 pp., figs. 1-94, I-XI.

STYRON, C.E. 1969. Taxonomy of two populations of an aquatic isopod, Lirceus fontinalis Raf. Amer. Midl. Natl., 28 (2):402-416.

WILLIAMS, W.D. 1972. Freshwater isopods (Asellidae) of North America. Biota of Freshwater Ecosystems, Ident. Manual No. 7, U.S. Environmental Protection Agency, 45 pp. 